数比亡消失係数との積により有效肝血流量を算出した. 以上各種パラメータ算出のプログラムを BASI 言語にて 開発し，血中消失曲線，肝拱取时線を再現して検查報告 書を作成した。本法は徒来法より簡便で或速かつ正確な 結果が得られ，日常ルチン検查としては利用度の高い， 臨床上きわめて有用な广法であると考えられた。

\section{9. 呼吸同期による肝シンチグラムの試み}

岩手医科大学附属病院中央放射線部

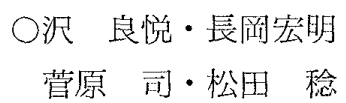
放射線医学教等 杜川茂彦

呼吸運動による動きを，呼吸波形として出力できるマ グネットニューモグラムを使用して，呼吸同期イメージ ングを試みた結果，実験上では，呼吸による移動距離， 呼吸回数，ゲートタイムが変化しても闰期効果は良好な 結果となった。臨床への応用では，呼吸性移動の著名な 症例に対しては同期効果は明確にあらわれ欠損の大きさ， 個数を良好に描出することができきた，しかし，烀吸状 態には個人差ぶあるため，同期されなかったり，撮影時 間が長くなるなど日常ルチンワークとして確立するには 未解決な問題が残されている。

460. スラントホールコリメータの骨シンチへの応用 (骨 盤部について)

自治医科大学附属病院中央放射線部

○旧村義文・黑田順平・神山辰彦

吉穚昌宏・増淵伸春

骨シンチにおいて骨盤部で問題になるのは残尿である。 われわれはこれを解決する方法として，検者を坐位にし て下から尾頭方向で撮る方法（パラレル法）を用いてき た. 今回スラントホールコリメータ $\left(35^{\circ}\right)$ を用いて試み るととにした，方法は検者が仰卧位で上から頭尾方向 (スラント 1 法), 腹卧位で上から尾頭方向（スラント 2 法), 仰卧位で下から尾頭方向（スラント 3 法）で撮る. 残尿が少ない時はスラント 1 法が適している. 残尿が多 い時はスラント 2,3 法である程度解決できる. 日営， 坐位にできる検者の場合，パラレル法を用い，動けない 検者の場合，スラント法を用いるのがよい.

461. ROI 決定に胸部X線写真を利用したエアゾール吸 入法

大阪市立大学医学部附属病院中央放射線部RI室

○下西祥裕・浜田国雄・池田穂積 大村昌弘・越智宏暢

エアゾール吸入シンチグラフィーの肺野の領域(ROI) 設定に，胸部X線写真を利用し，末梢肺への到達度执よ
び気道のクリアランスを求め, 彷来よりの矩形 ROI の 結果と比較し検討した。

未梢肺への到達度に関して本法が矩形 ROI 法上り精 度よく評価できた，気道のクリアランスに関しては，差 が見られなかった。

本法はトランスミッション法と比較しても, ○簡便で ある，○気管支の走行がわかる，○面線源を使わないの で被儤が少ない，などの利点を持つ.

462. 肺のトランスミッション像でのフーリエ解析の試 み

国立がんセンター

○福喜多博军・川合英夫・村上 兔 安西総業株式会社 藤田和男 島津製作所 伴 隆一

彷来心機能の測定に用いられているフーリエ変換から フェーズ，解析を䏒の動態トランスミッションに応用す るととにより, 振譚画像, 位相画像を得ることができた。 また同時に左右の換気曲線を得て, 術後の肺機能の回復 をみるととができた。本法を ${ }^{133} \mathrm{Xe}$ による換気曲線と比 較したところよく一致した。との方法は手技が簡単なと

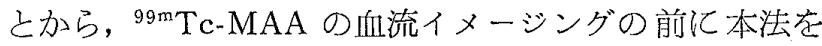
奥用すれば，読影上秀れた情報を提供するあのと思われ る. 今後の問題点として, 呼吸同期（Trigger 信号）の 取り出し方，換気曲線のフーリエ級数への fitting 方法 等が举げられるが，手法として臨床上有用であるため今 後一般に普及するものと思われる。

\section{Dual Isotope Scan の検討}

帝京大学医学部付属病院

放射線科核医学検査室

○新尾泰男・河洼雅宏・高階孝弘 高田賢二・長山春美

胆道玨建術症例の予後の観察手技として, 肝・胆道系 および上部消化器系を同時観察する目的で dual isotope scan を検討した。胆道系は， ${ }^{99 \mathrm{~m}} \mathrm{Tc}-\mathrm{PMT} 2.5 \mathrm{mCi}$ 静 注，消化器系は， ${ }^{111} \mathrm{In}$ DTPA $0.5 \mathrm{mCi}$ (プリンまたは 玉子豆腐 $150 \mathrm{~g}$ 亿混人）経口投与し， data 収集した。 当初10分から60分まで10分間隔で二核種交互収集を行っ たが，data の精度が悪く，動態収集の必然性が生じた。 そこで収集用メモリーを利用し二核種動態収集をした後 8 bit $の$ picture memory 4 bit ずつ 2 色のカラースケ 一ルを配し一画面上に二核種同時描画を行った。これに より食事内容物之胆汁の混合状態および逆流現象を視觉 上で観察が可能となった.

464. 経静脈法と経直腸法による門脈血流成分の検討 